\title{
Messenger RNAs encoding lipoprotein lipase, fatty acid synthase and hormone-sensitive lipase in the adipose tissue of underfed-refed ewes and cows
}

\author{
Muriel Bonnet ${ }^{\mathrm{a}}$, Yannick Faulconnier ${ }^{\mathrm{a}}$, Jeanne Fléchet ${ }^{\mathrm{a}}$, \\ Jean-François Hocquette ${ }^{b}$, Christine Leroux ${ }^{c}$, \\ Dominique Langin ${ }^{\mathrm{d}}$, Patrice Martin ${ }^{\mathrm{c}}$, Yves Chilliard ${ }^{\mathrm{a} *}$
}

\author{
${ }^{a}$ Laboratoire sous-nutrition des ruminants, Inra, Theix, \\ 63122 Saint-Genès-Champanelle, France \\ ${ }^{b}$ Laboratoire croissance et métabolismes des herbivores, Inra, \\ 63122 Saint-Genès-Champanelle, France \\ ${ }^{\mathrm{c}}$ Laboratoire de génétique biochimique et de cytogénétique, Inra, \\ 78352 Jouy-en-Josas cedex, France \\ d Institut Louis Bugnard, Hôpital Rangueil, Inserm U317, 31403 Toulouse cedex 4, France
}

(Received 6 October 1997; accepted 23 March 1998)

\begin{abstract}
The mechanisms involved in the nutritional regulation of genes encoding lipogenic (lipoprotein lipase (LPL) and fatty acid synthase (FAS)) and lipolytic (hormone-sensitive lipase (HSL)) enzymes were investigated by comparing the levels of the corresponding mRNAs in the adipose tissue (AT) of underfed or underfed-refed ewes and cows. Refeeding sharply increased LPL and FAS activities (19-25- and 6-8-fold, respectively) and moderately increased (2-4 fold) the activities of glucose-6-phosphate dehydrogenase (G6PDH), malic enzyme (ME) and glycerol-3-phosphate dehydrogenase $(\mathrm{G} 3 \mathrm{PDH})$. Northern blot analysis revealed three LPL transcripts and a single FAS transcript in cow and ewe AT. A single HSL mRNA was detected in cow AT and two transcripts in ewe AT. Refeeding sharply increased LPL and FAS mRNA levels, while restriction slightly increased (cows) or had no effect (ewes) on the HSL mRNA levels. This suggests that nutritional factors regulate sharply the expression of LPL and FAS genes by pretranslational mechanisms, but less clearly that of HSL gene. (O) Inra/Elsevier, Paris
\end{abstract}

ruminants / adipose tissue / enzyme activities / mRNAs / refeeding

* Correspondence and reprints

E-mail: chilliar@clermont.inra.fr 
Résumé - ARN messagers spécifiant la lipoprotéine-lipase, la synthétase des acides gras et la lipase hormono-sensible dans le tissu adipeux de brebis et de vaches sous-nutries puis réalimentées. Les mécanismes impliqués dans la régulation de l'expression des gènes codant pour des enzymes lipogéniques (LPL, FAS) et lipolytique (LHS), sont étudiés en comparant les taux des ARNm correspondants dans les TA de brebis et de vaches sous-nutries ou sous-nutries puis réalimentées. La réalimentation augmente fortement les activités LPL et FAS (19-25 fois et 6-8 fois, respectivement) et modérement les activités G6PDH, EM et G3PDH ( $2-4$ fois). L'étude par Northern blot révèle trois transcrits LPL, et un transcrit FAS dans les TA bovin et ovin. Un trancrit LHS est détecté dans le TA bovin et deux dans le TA ovin. Alors que les taux de transcrits LPL et FAS sont fortement augmentés par la réalimentation, la restriction n'augmente que légèrement (vache) ou ne modifie pas (brebis) le taux de transcrit LHS, suggérant que les facteurs nutritionnels régulent fortement par des mécanismes prétraductionnels l'expression des gènes LPL et FAS, mais peu celle du gène LHS. (C Inra/Elsevier, Paris

ruminants / tissu adipeux / activités enzymatiques / ARNm / réalimentation

\section{INTRODUCTION}

Several reports have shown that underfeeding inhibits the activity of lipogenic enzymes in ruminant adipose tissue (AT) while refeeding restimulates it $[3,8,18$, 41]. In contrast, underfeeding and refeeding have a stimulatory and an inhibitory effect, respectively, on lipolytic enzymes [43]. In monogastric species, the responses of AT lipogenic and lipolytic enzymes to underfeeding and/or refeeding are due either to changes in mRNA levels $[7,10$, $22,28,43]$ or to changes in post-translational events $[9,30]$ depending on the duration and intensity of the nutritional treatments. The molecular mechanisms involved in the nutritional regulation of AT gene expression have not been studied in ruminant species. Therefore, we examined the effect of underfeeding and refeeding on the mRNA levels of lipoprotein lipase (LPL, which regulates fatty acid uptake), fatty acid synthase (FAS, which partly regulates fatty acid synthesis) and hormone-sensitive lipase (HSL, which catalyses the rate-limiting step in AT lipolysis), simultaneously to changes in the activity of several lipogenic enzymes, i.e. LPL, FAS, glucose-6-phosphate dehydrogenase (G6PDH), malic enzyme (ME) and glycerol-3-phosphate dehydrogenase (G3PDH).

\section{MATERIALS AND METHODS}

\subsection{Animals, diets, adipose tissue cellularity and enzyme activities}

Adult non-lactating non-pregnant Holstein cows ( $n=4,4$ - to 9-year-old) and Lacaune ewes ( $n=4,2$ - to 6-year-old) were used. They received a restricted diet (that provided approximately $20 \%$ of the estimated maintenance energy requirement (MER), Inra [19]) of straw $(1 \mathrm{~kg} /$ day $)$ and hay $(1.5 \mathrm{~kg} /$ day) for cows, and straw only ( $400-500 \mathrm{~g} /$ day) for ewes, for 10 or 8 days, respectively. Half the animals were then slaughtered, while the remaining were refed (approximately $220 \%$ of MER, with ad libitum access to hay and water plus defined levels of concentrate) for 21 (cows) and 10 (ewes) days, as described by Chilliard and Faulconnier [2]. Cows were killed with a captivebolt humane procedure, and ewes were exsanguinated. Average weights at slaughter were 57 and $59 \mathrm{~kg}$ for underfed and refed ewes, and 547 and $665 \mathrm{~kg}$ for underfed and refed cows, respectively.

After death, samples of perirenal AT were either placed immediately at $37^{\circ} \mathrm{C}$ for adipocyte volume determination [34] or frozen in liquid nitrogen and stored at $-80^{\circ} \mathrm{C}$ until assays of lipogenic enzyme activities were performed or the RNA extracted and quantified. LPL activity was measured using an artificial emulsion containing ${ }^{3} \mathrm{H}$-triolein after a detergent (Deoxycholate-Nonidet $\mathrm{P}_{40}$ ) extraction procedure [11]. The FAS, G3PDH, G6PDH and ME activities were assayed spectrophotometrically as described previously [4]. 


\subsection{RNA extraction and northern blot analysis}

Total RNA was extracted using the acid guanidium thiocyanate/phenol/chloroform procedure, as described by Chomczynski and Sacchi [6], with some modifications. First, in order to improve the RNA yield, lipids were removed by centrifugation for $30 \mathrm{~min}$ at $3000 \mathrm{~g}$, immediately after tissue homogenization. Second, the extraction and precipitation steps were repeated twice to improve the purity of RNA. The final RNA pellets were solubilized in water. RNA concentration was determined by spectrophotometry $(260 \mathrm{~nm})$ and the integrity was systematically checked by electrophoresis on a $1 \%$ agarose gel stained with ethidium bromide and visualized under ultraviolet fluorescence.

For northern blot analysis, $40 \mu \mathrm{g}$ of total RNA was denatured for $15 \mathrm{~min}$ at $70^{\circ} \mathrm{C}$ in running buffer ( $20 \mathrm{mM} 3-(\mathrm{N}$-morpholino) propanesulfonic acid (MOPS), $10 \mathrm{mM}$ sodium acetate, $1 \mathrm{mM}$ EDTA) (pH 7.0), containing $6.7 \%$ formaldehyde and $50 \%(\mathrm{vol} / \mathrm{vol})$ formamide, and then resolved by electrophoresis on a $6.5 \%$ formaldehyde- $1 \%$ agarose gel. Thereafter, total RNA was transferred to a nylon membrane (GeneScreen, NEN Life Science Products, USA) by electric blotting for $3 \mathrm{~h}$ in 20 $\mathrm{mM}$ Tris, $10 \mathrm{mM}$ sodium acetate and $0.5 \mathrm{mM}$ EDTA, $\mathrm{pH} 8.0$ [16]. The membrane was subsequently prehybridized $(2 \mathrm{~h})$ and hybridized $(16-24 \mathrm{~h})$ at $42{ }^{\circ} \mathrm{C}$ in $20 \%$ deionized formamide, $5 \mathrm{X}$ Denhardt's solution $(0.1 \%$ polyvinylpyrrolidone, $0.1 \%$ ficoll, $0.1 \%$ BSA), $3 \mathrm{X}$ SSPE $\left(0.45 \mathrm{M} \mathrm{NaCl}, 30 \mathrm{mM} \mathrm{NaH}_{2} \mathrm{PO}_{4}, 3 \mathrm{mM}\right.$ EDTA) (pH 7.4), 1 \% SDS, $9 \%$ Dextran sulfate, and $275 \mu \mathrm{g} / \mathrm{mL}$ denatured salmon sperm DNA. The cDNA probes were labelled by random priming (Nonaprimer labelling kit, Appligène, Illkirch, France) with [ $\left.\alpha_{-}^{32} \mathrm{P}\right] \mathrm{dCTP}(3$ $000 \mathrm{Ci} / \mathrm{mmol}$; NEN Life Science Products, USA) and added $\left(1 \times 10^{6} \mathrm{cpm} / \mathrm{mL}\right)$ to the prehybridization mixture. The membrane was washed twice at $20^{\circ} \mathrm{C}$ for $15 \mathrm{~min}$ in $2 \mathrm{XSSPE}$, $2 \%$ SDS, twice at $55^{\circ} \mathrm{C}$ for $15 \mathrm{~min}$ in $2 \mathrm{X}$ SSPE, $0.1 \%$ SDS, and twice at $65^{\circ} \mathrm{C}$ for 10 $\min$ in $0.1 \mathrm{X}$ SSPE, $0.1 \%$ SDS.

Autoradiograms (Hyperfilm-MP, Amersham, France) were obtained after exposure for between $12 \mathrm{~h}$ and 5 days at $-80^{\circ} \mathrm{C}$ using intensifying screens. The autoradiograms were scanned with the Apple Scan program (Macintosh). Quantification was performed by analysing the images with the NIH Image 1.54 program (Macintosh).

\section{3. cDNA probes}

An approximately 1000 -bp fragment of LPL DNA was prepared by a reverse transcription-polymerase chain reaction assay starting from the goat mammary gland RNA, using nucleotides 1 803-1 823 to 2782-2 803 of the human sequence described by Wion et al. [45]. Reverse transcription was carried out using the Moloney murine leukemia virus (MMLV) reverse transcriptase (Gibco BRL, Life Technologies) following the manufacturer recommendations. PCR was performed essentially as described by Saiki et al. [35] using the oligonucleotides 5'- GTATAGTGGCCAAATAGCACA - 3' as the sense primer and 5'GTTCACTCACTCTTGACTAGTT - 3 ' as the antisense primer. After an initial denaturing step $\left(94^{\circ} \mathrm{C}\right.$ for $10 \mathrm{~min}$ ), the reaction was subjected to the following three-step cycle, which was repeated 35 times: denaturation for $1 \mathrm{~min}$ at $94{ }^{\circ} \mathrm{C}$, annealing for $2 \mathrm{~min}$ at $50{ }^{\circ} \mathrm{C}$, and extension for $2 \mathrm{~min}$ at $72{ }^{\circ} \mathrm{C}$. The identity of the goat LPL probe was confirmed by sequencing approximately $250 \mathrm{pb}$ of each extremity of the PCR product. This goat sequence showed 84,77 or $66 \%$ identity with the previously determined cow, pig and human sequences, respectively. The bovine LPL cDNA probe cloned by Senda et al. [39] was used concurrently to confirm results obtained with the goat LPL probe. The FAS probe was a $280-b p$ fragment of the FAS CDNA from a goat mammary gland inserted into the SmaI site of pUC18 [27]. The HSL probe was the entire human cDNA (approximately $2800 \mathrm{bp}$ ) inserted into the EcoRI site of pBluescript SK [24]. The $\beta$-actin probe corresponded to $236 \mathrm{bp}$ of the human cDNA inserted into the EcoRI site of the pBluescript SK and was used as an internal control of sample loading and recovery.

\subsection{Statistical analysis}

Data were normalized by log transformation and analysed with the GLM procedures of SAS [36] The model included the effect of species (ovine versus bovine) and feeding level (underfed versus refed). Results from the model including the interaction between species and feeding level are presented only for HSL and $\beta$-actin mRNA amounts because, due to the small sample size, the interaction was never significant for the other parameters measured. 


\section{RESULTS}

\subsection{Effect of refeeding on lipogenic enzyme activities}

Refeeding sharply increased LPL and FAS activities expressed per $10^{6}$ adipocytes $(P<0.001$ and $P<0.03$, respectively) by a factor of 25 (ewes) and 19 (cows) for LPL and 6 (ewes) and 8 (cows) for FAS (table I). In contrast, the activities of enzymes generating NADPH (G6PDH and $\mathrm{ME}$ ), or enzyme generating glycerol3-P (G3PDH) were only two-fold (ewes) or four-fold (cows) higher $(P<0.08$, $P<0.06, P<0.01$, respectively) in refed than in underfed animals. Similar trends were observed when these activities were expressed per gram of AT (table I).

Moreover, G3PDH $(\times 2.3, P<0.05)$ and more markedly G6PDH $(\times 7.8, P<0.01)$ activities were significanly higher or tended to be higher $(\mathrm{ME}, \times 2.5, P<0.13)$ in cow than in ewe AT, whereas no significant difference in LPL and FAS activities was observed between the two species.

\subsection{Effect of refeeding on total RNA and on LPL, FAS and HSL mRNA levels}

The yield of extracted RNA per $10^{6}$ adipocytes was higher $(P<0.004)$ in the AT of refed $(59 \mu \mathrm{g})$ than underfed $(22 \mu \mathrm{g})$ animals (table II). However, the level of total RNA was similar in both species.

Northern blot analysis (figure 1) shows that specific mRNA was found at 1.7, 3.4 and $3.8 \mathrm{~kb}$ approximately, for the goat LPL probe. The 3.4-kb LPL transcript was the more abundant both in cow and ewe AT. Similar trends were obtained when the northern blot was hybridized with the bovine LPL probe (data not shown). A single FAS mRNA of $8.7 \mathrm{~kb}$ was observed in the AT of both species. The human HSL cDNA probe revealed only one 3 - $\mathrm{kb}$ trans- cript in cow AT whereas two transcripts were observed at 3 and $4.3 \mathrm{~kb}$ in ewe AT (figure 1). The human $\beta$-actin cDNA probe revealed a single $2.2-\mathrm{kb}$ transcript.

LPL and FAS mRNAs were barely detectable and could not be quantified in the AT of restricted ewes and cows, whereas the transcripts were well expressed in the AT of refed animals. In contrast, the AT level of HSL mRNA was not significantly different between underfed and refed animals (table $I I$ ). However, significant $(P<0.03)$ species and species $\times$ feeding level effects suggest a significant increase in HSL mRNA amount in AT of restricted cows. The signal obtained for $\beta$-actin mRNA was nearly two-times higher $(P<0.01)$ in refed than in underfed animals (table II), and this is more evident in cows AT owing to significant $(P<$ $0.01)$ species and species $\times$ feeding level effects. The HSL/ $\beta$-actin mRNA ratio was significantly increased in AT of restricted cows owing to significant feeding level $(P<0.05)$ and species $\times$ feeding level $(P<0.01)$ effects.

\section{DISCUSSION}

In addition to the simultaneous assays of LPL, FAS, G6PDH, EM and G3PDH activities, which give information on a part of three lipogenic pathways (fatty acid uptake: LPL, fatty acid synthesis: FAS, G6PDH, EM, and synthesis of glycerol3-phosphate: G3PDH), this study brings novel information about gene expression in AT of underfed-refed cows and ewes. This concerns the sizes of the different transcripts of LPL, FAS and HSL, concurrently with the response of the mRNA amounts to changes in nutritional status. However, these results must be confirmed in a larger number of animals being before to be extended to the general population. 


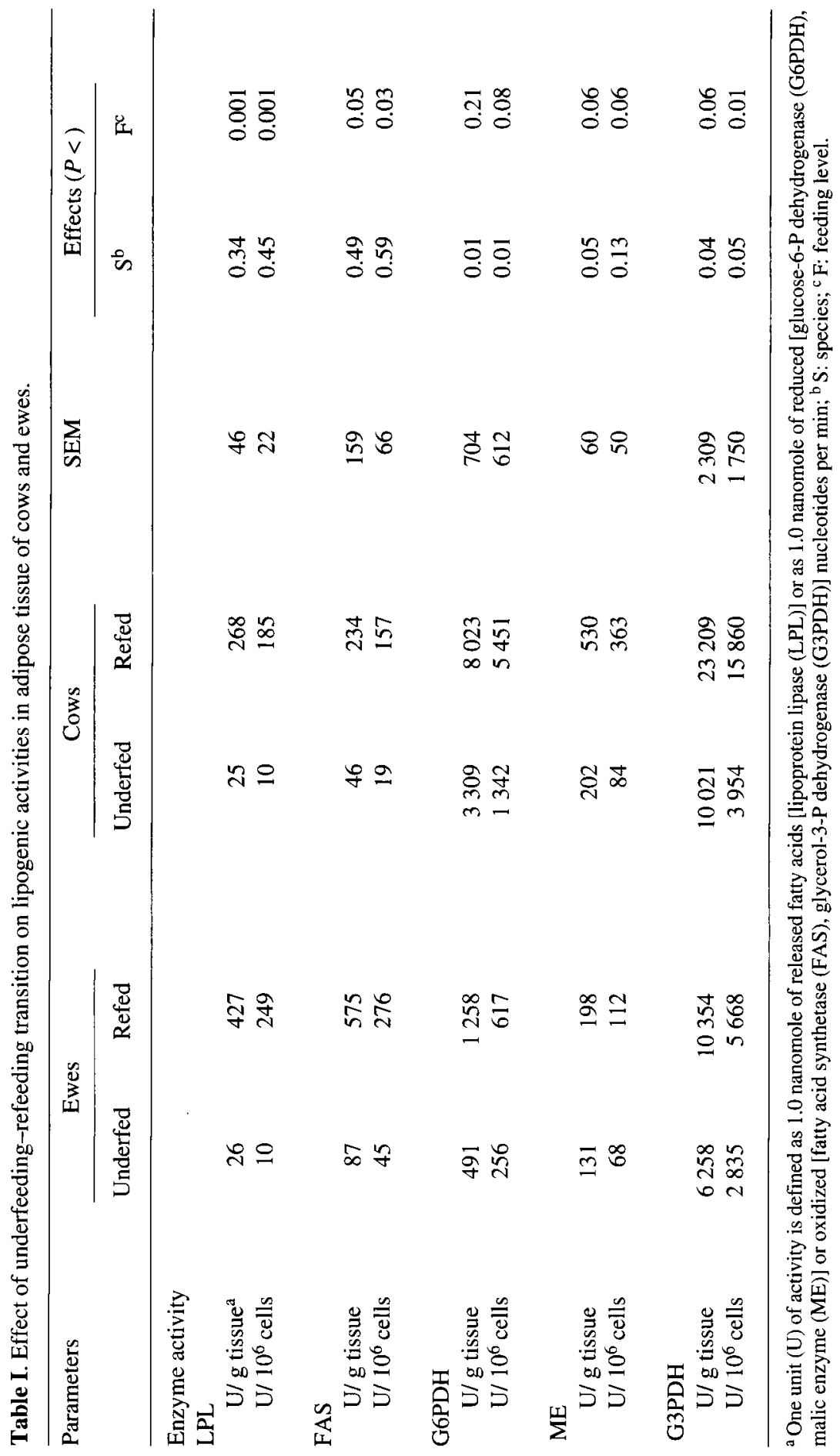




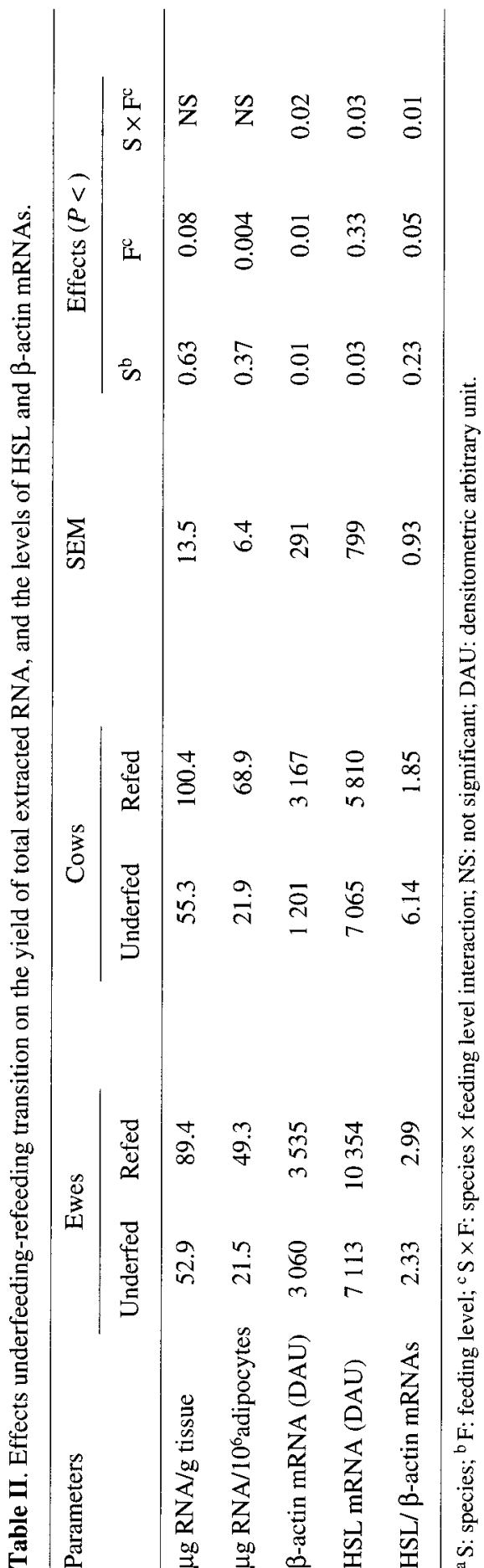

\subsection{Lipogenic enzyme activities}

In this work, LPL and G3PDH activities of AT were measured simultaneously with FAS, G6PDH and ME for the first time in underfed-refed ruminants. Results are consistent with the increase in the activity of lipogenic enzymes previously measured when refeeding restricted ruminants. The activities of LPL and FAS (two keyenzymes) were more responsive than the less limiting or less regulated $\mathrm{G} 6 \mathrm{PDH}$, ME and G3PDH activities [44]. The increase in the LPL activity is consistent with previous results from Chilliard et al. [3] and DiMarco et al. [8], who observed that refeeding 2-day-fasted goats for 7 days or 9-day-underfed steers for 21-35 days increased the LPL activity by a factor of 12 (goats) and 3-7 (steers). The increase in FAS activity with refeeding is higher than the slight increase $(+4 \%)$ observed in the subcutaneous AT after refeeding 8-dayfasted lambs [18], but this is logical because their refeeding was only at $80 \%$ MER, whereas our refeeding was approximately at $220 \%$ MER. The same pattern of response for FAS activity $(+84 \%$ ) was observed by Smith et al. [41] in subcutaneous AT of 4-day-fasted steers refed for 8 days. The activities of NADPH-generating enzymes (G6PDH and $\mathrm{ME}$ ) and the glycerol-3-P-providing enzyme (G3PDH) were 2- to 4-fold higher in the AT of refed as compared to underfed ewes and cows. Smaller but significant variations were observed for G6PDH [18, 32] and ME [18] activities in the AT of underfed-refed lambs and steers. There is no information in the literature about the variation in the G3PDH activity in ruminant AT as a function of refeeding. Nevertheless, previous results indicated that the G3PDH activity was positively correlated with the energy balance of cows [4] and ewes [38], as were other lipogenic enzyme activities (LPL, FAS, G6PDH, ME).

Furthermore, G3PDH and especially G6PDH activities were higher in cows 


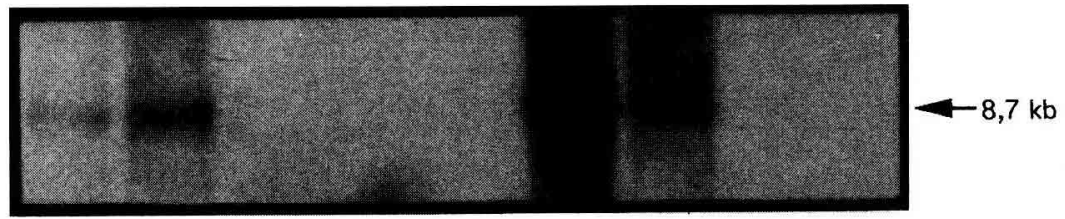

HSL
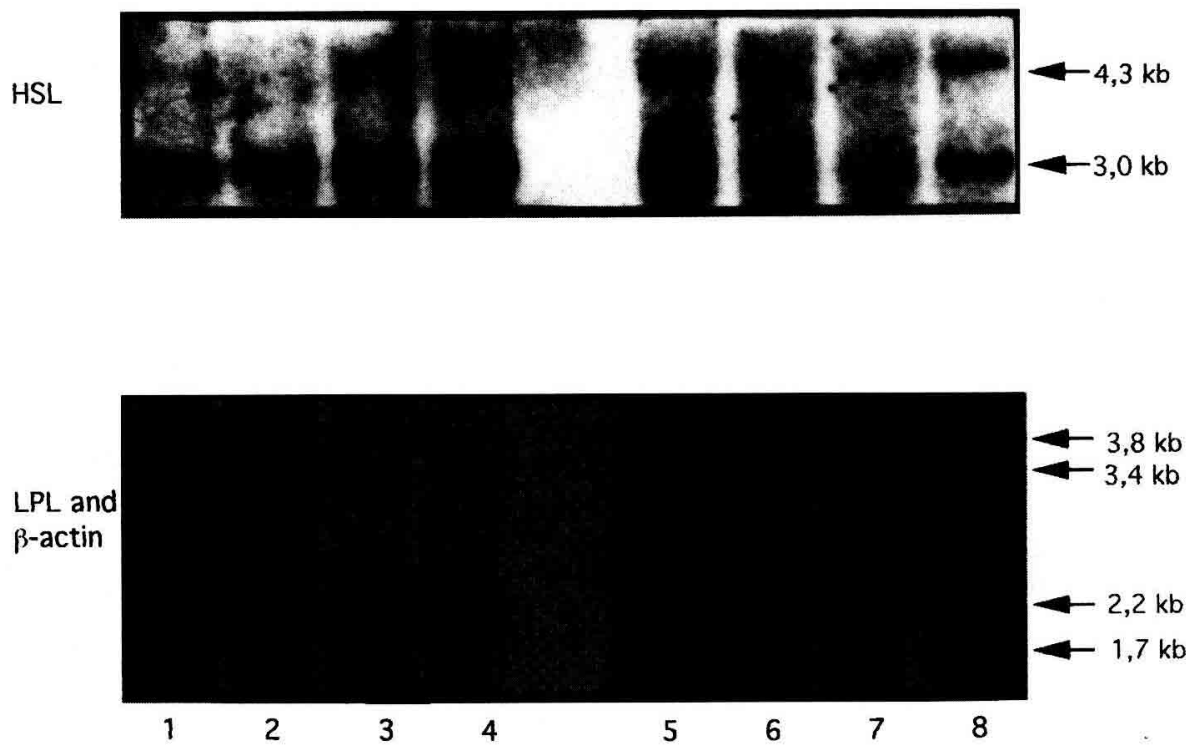

Figure 1. Northern blot analysis of fatty acid synthase (FAS), hormone-sensitive lipase (HSL), lipoprotein lipase (LPL) and $\beta$-actin mRNAs in ewe and cow adipose tissue. Forty micrograms of total RNA from restricted (lanes 3, 4, 7, 8) or refed (lanes 1,2,5,6) cows (lanes 1-4) and ewes (lanes 5-8) was hybridized with the LPL, FAS, HSL and $\beta$-actin probes as described in the text. RNA molecular weight markers ( $8 \mu \mathrm{g}$, Life Technologies) were used as size markers.

than in ewes, whereas LPL and FAS activities did not significantly differ between the two species. These species differences are in agreement with results from Chilliard et al. [4], Sebastian et al. [38] and Faulconnier et al. [12], but their physiological meaning remains to be elucidated. However, Smith and Prior [40] reported a FAS activity significantly greater in ovine than in bovine subcutaneous AT, whilst the G6PDH activity did not differ. These differences with our results could arise from differences in animal breeds, AT anatomical sites, feeding conditions or analytical methods, between studies in the two Laboratories.

\subsection{RNAs of adipose tissue}

The increases in the lipogenic activities with refeeding may be related to variations in the synthesis rate of these enzymes. In an attempt to investigate one 
of the early events involved in the synthesis of LPL and FAS, and the lipolytic enzyme, HSL, we estimated variations in the level of their specific mRNAs.

We extracted total RNA using a modified version of the method of Chomczynski and Sacchi [6]. The RNA yield were similar to the values of 25-127 $\mu \mathrm{g}$ RNA extracted by Cameron et al. [1] from $10^{6}$ subcutaneous adipocytes of ad libitum-fed growing steers. These authors used another modification (lipids were removed by two washes with chloroform) of the method of Chomczynski and Sacchi. In our study, the level of RNA recovered was higher in the AT of refed than underfed animals, suggesting that the overall cellular metabolic activity is higher in the refed state.

Northern blot analysis allowed us to identify three LPL mRNAs (1.7, 3.4 and $3.8 \mathrm{~kb}$ ) in cow and ewe AT. The existence of three transcripts of different sizes is in agreement with data and size ranges from Kirchgessner et al. [21] and Senda et al. [39] in cow mammary gland and Ladu et al. [23] and Graulet et al. [15] in bovine muscles. The different sizes of the three LPL transcripts could be due to a random choice of polyadenylation signals as suggested for AT LPL in mice [21] and humans [45]. In agreement with this hypothesis, two polyadenylation signals have been described for the partial sequence of cow mammary gland LPL cDNA [39]. Moreover, sequencing the entire 3' untranslated region of the ovine LPL cDNA, allowed us to identify three polyadenylation signals (M. Bonnet et al., unpublished results). As in the cow mammary gland [39] and human AT [33], the transcript of intermediate size was predominant in our study, suggesting that the second polyadenylation site is preferentially used in the AT of refed ruminants.

A single FAS mRNA of about $8.7 \mathrm{~kb}$ was detected in ewe and cow AT. These first data obtained in ruminant species are in agreement with results from Paulauski and Sul [31] in mouse liver and Milder and Clarke [29] in pig AT. In contrast, two mRNAs of approximately 8.5 and $9.2 \mathrm{~kb}$ were described in rat AT [13, 14], mammary gland [37] and liver [26, 46]. In pig, Milder and Clarke [29] described a mutated non-functional polyadenylation signal that might explain the alternative presence of the two FAS transcripts depending on species.

A single HSL mRNA was identified in cow AT and two in ewe AT. Although no published data are available in ruminant species, a HSL mRNA of about $3 \mathrm{~kb}$ has been described in the rat [17], human [24] and pig [28] AT. Interestingly, unlike the rat testis, where a single HSL mRNA of $3.9 \mathrm{~kb}$ is expressed [17], two different HSL mRNAs of 3.3 and $3.9 \mathrm{~kb}$ were found at approximately equal levels in human testis [42]. The larger HSL mRNA arises from the addition of a testis-specific coding exon, which is located $16 \mathrm{~kb}$ upstream from the exons encoding adipocyte HSL. As in human testis, the two HSL mRNAs of different sizes in ewe AT might be due to the alternative use of transcription initiation signals. Nevertheless, the occurrence of two transcripts in ewe AT could also be due to the use of alternative polyadenylation signals, or alternative splicing.

The increase in the $\beta$-actin mRNA level with refeeding could be related to the increase in total RNA, suggesting a general anabolic pattern in the fed state. This general trend, however, does not seem to be sufficient to account for the strong stimulatory effects on LPL and FAS mRNAs, suggesting a specific effect of refeeding on these mRNAs.

Refeeding sharply increased, indeed, the level of LPL and FAS mRNAs in AT of ewes and cows. Although FAS mRNA amounts varied between refed animals, these individual variations were lower than variations induced by nutritional treatment 
(figure 1). This response to refeeding of LPL transcripts in ruminant AT is in agreement with the results of Enerbäck et al. [10], Cooper et al. [7] and Ladu et al. [9] who reported increases in LPL mRNAs in refed guinea pig, chicken and rat $\mathrm{AT}$, respectively. However, Doolittle et al. [22] reported that the $50 \%$ decrease in AT LPL activity caused by an overnight fast was mediated primarily by alterations in posttranscriptional events involved in enzyme processing. LPL regulatory responses to this short-term food deprivation seem to be different from the pre-translational regulatory mechanisms involved during prolonged fasting. No published data are available concerning the response of FAS mRNA to refeeding in the AT of laboratory or farm animals. Nevertheless, an increase in FAS mRNA level was observed in the liver of refed rats [20] and mice [31]. It is important to note that the increase in LPL and FAS mRNA levels could be due to an increased transcription rate or to an increase in the half-life of the corresponding mRNAs. Further studies are needed to answer this question.

The 3-fold increase in the HSL mRNA level (normalized to $\beta$-actin mRNA) in restricted versus refed cows, is consistent with the results from Sztalryd and Kraemer [43] and Liu et al. [28] who observed a 2-fold increase in the AT of 3- to 5-dayfasted rats and 2-day-fasted pigs, respectively. The absence of significant variation in HSL mRNA amount in ewe AT contrasts with these results. However, the result we obtained in cow AT must be confirmed in a larger number of animals to ensure that the variation in the HSL gene expression clearly results from the nutritional treatment and not from individual variations or from variations in the amount of total RNA used for the northern blot study. It is interesting to note that significant changes in rat HSL expression require extreme periods (3-5 days) of fasting [43] suggesting that the short-term regulation of HSL activity occurs prima- rily via post-translational mechanisms [25]. Ruminant species require several days to achieve the fasting state in contrast to non-ruminant species which only require several hours. Thus, the length of our semi-starvation treatment was probably not sufficient to induce an unquestionable pretranslational regulation of HSL gene expression. This low response of HSL mRNA amount with restriction could be related to the inconsistency of the effects of fasting or underfeeding on in vitro basal and/or cathecolamine-stimulated lipolysis in ruminant AT [5, 41]. Further experiments are needed to identify which mechanism (pre- versus post-translational) predominates in the regulation of HSL gene expression depending on the length of fasting and/or refeeding.

In conclusion, this study provides new data on the mRNAs encoding LPL, FAS and HSL in ruminant AT. The size of the different transcripts has been estimated. The response to refeeding was studied using a nutritional protocol causing a large response in the activities of lipogenic enzymes, and a strong increase in LPL and FAS mRNAs, suggesting a regulation of these enzyme activities by pretranslational mechanisms during refeeding. In addition, the absence (ewes) or the slight decrease (cows) of the HSL mRNA level suggests that the regulatory mechanisms controlling lipolytic and lipogenic capacities are quite different.

\section{ACKNOWLEDGEMENTS}

We thank F. Le Provost for kindly providing us with the FAS cDNA probe, and C. Vaury for advice and help in northern blot analysis, as well as A. Ollier, J.P. Pezant and their team for managing the animals, and G. Cuylle and his team for slaughtering the animals. This work was financially supported by an Inra grant from the Action Incitative Programmée (AIP): 'Lipogenèse chez les espèces d'intérêt zootechnique' (Lipogenesis in farm animals). 


\section{REFERENCES}

[1] Cameron P.J., Rogers M., Omans J., May S.G., Lunt D.K., Smith S.B., Stearoyl coenzyme A desaturase enzyme activity and mRNA levels are not different in subcutaneous adipose tissue from Angus and American Wagu Steers, J. Anim. Sci. 72(1994) 2624-2628.

[2] Chilliard Y., Faulconnier Y., Insulin and (or) dexamethasone regulation of glucose and acetate utilization in ovine and bovine adipose tissue incubated for seven days, J. Anim. Sci. 73 (1995) 2063-2070.

[3] Chilliard Y., Sauvant D., Morand-Fehr P., Goat mammary, adipose and milk lipoprotein lipases, Ann. Rech. Vet. I0 (1979) 401-403.

[4] Chilliard Y., Gagliostro G., Fléchet J., Lefaivre R., Sebastian I., Duodenal rapeseed oil infusion in early and midlactation cows. 5 . Milk fatty acid and adipose tissue lipogenic activities, J. Dairy Sci. 74 (1991) 1844-1854.

[5] Chilliard Y., Doreau M., Bocquier F., Lobley G.E., Digestive and metabolic adaptations of ruminants to variations in food supply, in: Journet M., Grenet E., Farce M.H., Thériez M., Demarquilly C. (Eds.), Recent Developments in Nutrition of Herbivores, Proceedings of the IVth International Symposium on the Nutrition of Herbivores, Inra Editions, Paris, 1995, pp. 329-360.

[6] Chomczynski P., Sacchi N., Single-step method of RNA isolation by acid guanidium thiocyanate-phenol-chloroform extraction, Anal. Biochem. 162 (1987) 156-159.

[7] Cooper D.A., Stein J.C., Strieleman P.J., Bensadoun A., Avian adipose lipoprotein lipase: cDNA sequence and reciprocal regulation of mRNA levels in adipose tissue and heart, Biochim. Biophys. Acta 1008 (1989) 92-101.

[8] DiMarco N.M., Beitz D.C., Whitehurst G.B., Effect of fasting on free fatty acid, glycerol and cholesterol concentrations in blood plasma and lipoprotein lipase activity in adipose tissue of cattle, J. Anim. Sci. 52 (1981) $75-82$.

[9] Doolittle M.H., Ben-Zeev O., Elovson J., Martin D., Kirchgessner T.G., The response of lipoprotein lipase to feeding and fasting, $\mathrm{J}$. Biol. Chem. 265 (1990) 4570-4577.

[10] Enerbäck S., Semb H., Tavernier J., Bjursell G., Olivecrona T., Tissue specific regulation of guinea pig lipoprotein lipase; effect of nutritionnal state and tumor necrosis factor on mRNA levels in adipose tissue, heart and liver, Gene 64 (1988) 97-106.
[11] Faulconnier Y., Thévenet M., Fléchet J., Chilliard Y., Lipoprotein lipase and metabolic activities in incubated bovine adipose tissue explants: Effects of insulin, dexamethasone, and fetal bovine serum, J. Anim. Sci. 72 (1994) 184-191.

[12] Faulconnier Y., Guillon L., Chilliard Y., Lipoprotein lipase and Glucose-6-phosphate dehydrogenase activities in bovine and ovine adipose tissue incubated for 7 days: Effects of insulin and/or dexamethasone, Comp. Biochem. Physiol. 113 B (1996) 421-426.

[13] Foufelle F., Gouhot B., Perdereau D., Girard J., Ferré P., Regulation of lipogenic enzyme and phosphoenolpyruvate carboxykinase gene expression in cultured white adipose tissue. Glucose and insulin effects are antagonized by cAMP, Eur. J. Biochem. 223 (1994) 893-900.

[14] Guichard C., Dugail I., Le Liepvre X., Lavau M., Genetic regulation of fatty acid synthase expression in adipose tissue: overtranscription of the gene in genetically obese rat, J. Lipid. Res. 33 (1992) 679-687.

[15] Graulet B., Hocquette J.F., Bauchart D., Lipoprotein lipase activity and gene expression in heart and skeletal muscles in the preruminant calf, Proc. Nutr. Soc. 55 (1996) 18A.

[16] Hocquette J.F., Graulet B., Castiglia-Delavaud C., Bornes F., Lepetit N., Ferre P., Insulin-sensitive glucose transporter transcript levels in calf muscles assessed with a bovine GLUT 4 cDNA fragment, Int. J. Biochem. Cell. Biol. 28 (1996) 795-806.

[17] Holm C., Kirchgessner T.D., Svenson K.L., Fredrikson G., Nilson S., Miller C.G., Shively J.E., Heinzmann C., Sparkes R.S., Mohandas T., Lusis A.J., Belfrage P., Schotz M.C., Hormone-sensitive lipase: sequence and chromosomal localisation to 19 centq13.3, Science 241 (1988) 1503-1506.

[18] Ingle D.L., Bauman D.E., Mellenberger R.W., Johnson D.E., Lipogenesis in the ruminant: effect of fasting and refeeding on fatty acid synthesis and enzymatic activity of sheep adipose tissue, J. Nutr. 103 (1973) 1479-1488.

[19] Institut national de la recherche agronomique (Inra), Recommended allowances and feed tables, in: Jarrige R. (Ed.), Ruminant Nutrition, John Libbey Eurotext, Montrouge, 1989.

[20] Katsurada A., Iritani N., Fukuda H., Matsumura Y., Nishimoto N, Noguchi T., Tanaka $T$., Effects of nutrients and hormones on transcriptional and post-transcriptional regulation of fatty acid synthase in rat liver, Eur. J. Biochem. 190 (1990) 427-433.

[21] Kirchgessner T.G., Svenson K.L., Lusis A.J., Schotz M.C., The sequence of cDNA encoding lipoprotein lipase, J. Biol. Chem. 262 (1987) 8463-8466. 
[22] Ladu M.J, Kapsas H., Palmer W.K., Regulation of lipoprotein lipase in adipose and muscle tissues during fasting, Am. J. Physio. 260 (1991) R953-R959.

[23] Ladu M.J., Schultz C.J., Essig D.A., Palmer W.K., Characterization of serum-stimulated lipoprotein lipase from bovine heart, Int. J. Biochem. 23 (1991) 405-411.

[24] Langin D., Laurell H., Stenson Holst L., Belfrage P., Holm C., Gene organization and primary structure of human hormone-sensitive lipase: possible significance of a sequence homology with a lipase of Moraxella TA144, an antarctic bacterium, Proc. Natl. Acad. Sc.i USA 90 (1993) 4897-4901.

[25] Langin D., Holm C., Lafontan M., Adipocyte hormone-sensitive lipase: a major regulator of lipid metabolism, Proc. Nutr. Soc. 55 (1996) 93-109.

[26] Laux T., Schweizer M., Dietary-induced pretranslational control of rat fatty acid synthase, Biochem, J. 266 (1990) 793-797.

[27] Le Provost F., Lepingle A., Martin P., A survey of goat genome transcribed in the lactating mammary gland, Mam. Genome 7 (1996) $657-666$.

[28] Liu C.Y., Liang L.C., Chang L.C., Differential responses of hormone-sensitive lipase gene to nutritional transition in adipose tissue, liver, and skeletal muscle of pigs, Biochem. Mol. Bio. Int. 26 (1995) 689-694.

[29] Milder AM, Clarke S.D., Porcine fatty acid synthase, cloning of a complementary DNA, tissue distribution of its mRNA and suppression of expression by somatotropin and dietary protein, J. Nutr. 121 (1991) 900-907.

[30] Olivers J.D., Rogers M.P., Stimulation of lipoprotein lipase synthesis by refeeding, insulin and dexamethasone, Biochem. J. 292 (I993) 525-530.

[31] Paulauskis J.D., Sul H.S., Hormonal regulation of mouse fatty acid synthase gene transcription in liver, J. Biol. Chem. 264 (1989) 574-577.

[32] Pothoven M.A., Beitz D.C., Changes in fatty acid synthesis and lipogenic enzymes in adipose tissue from fasted and fasted-refed steers, J. Nutr. 105 (1975) 1055-1061.

[33] Ranganathan G., Ong J.M., Yukht A., Saghizadeh M., Simsolo R.B., Pauer A., Kern P.A., Tissue-specific expression of human lipoprotein lipase; effect of the 3'-untranslated region on translation, J. Biol. Chem. 270 (1995) 7149-7155.
[34] Robelin J., Agabriel J., Estimation de l'état d'engraissement des bovins vivants à partir de la taille des cellules adipeuses, Bull. Tech. CRVZ Theix, Inra 66 (1986) 34-41.

[35] Saiki R., Gelfand D., Stoffel S., Scharf S., Higuchi R., Horn G., Mullis K., Erlich H., Primer-directed enzymatic amplification of DNA with a thermostable DNA polymerase, Science 239 (1988) 487-491.

[36] SAS/STAT, Guide for personal computers, version 6, SAS Institute Inc., Cary, North Carolina, 1987.

[37] Schweizer M., Takabayashi K., Laux T., Beck K.F., Schreglmann R., Rat mammary gland fatty acid synthase: localization of the constituent domains and two functional polyadenylation/termination signals in the cDNA, Nucleic Acids Res. 17 (1989) 567-586.

[38] Sebastian I, Chilliard Y,, Purroy A., Jaime C., Supplémentation en céréales, état corporel et enzymes lipogéniques du tissu adipeux chez la brebis Aragonesa, Ann. Zootech. 42 (1993) 299-313.

[39] Senda M., Oka K., Brown W.V., Qasba P.K., Molecular cloning and sequence of a cDNA coding for bovine lipoprotein lipase, Proc. Natl. Acad. Sci. USA 84 (1987) 4369-4373.

[40] Smith S.B., Prior R.L., Comparisons of lipogenesis and glucose metabolism between ovine and bovine adipose tissues, J. Nutr. 116 (1986) 1279-1286.

[41] Smith S.B., Prior R.L., Mersmann H.J., Interrelationships between insulin and lipid metabolism in normal and alloxan-diabetic cattle, J. Nutr. 113 (1983) 1002-1015.

[42] Stenson Holst L., Langin D., Mulder H., Laurell H., Grober J., Bergh A., Mohrenweiser H.W., Edgren G., Holm C., Molecular cloning, genomic organisation, and expression of testicular isoform of hormone-sensitive lipase, Genomics 35 (1996) 441-447.

[43] Sztalryd M.A., Kraemer F.B., Regulation of hormone-sensitive lipase during fasting, Am. J. Physiol. 266 (1994) E179-E185.

[44] Vernon R.G., Lipid metabolism in the adipose tissue of ruminant animals, Prog. Lipid. Res. 19 (1980) 23-106.

[45] Wion K.L., Kirchgessner T.G., Lusis A.J., Schotz M.C., Lawn R.M., Human lipoprotein lipase complementary DNA sequence, Science 235 (1987) 1638-1641.

[46] Yan C., Wood E.A., Porter J.W., Characterization of fatty acid synthase cDNA clone and its mRNA, Biochem. Biophys. Res. Com. 126 (1985) 1235-1241. 